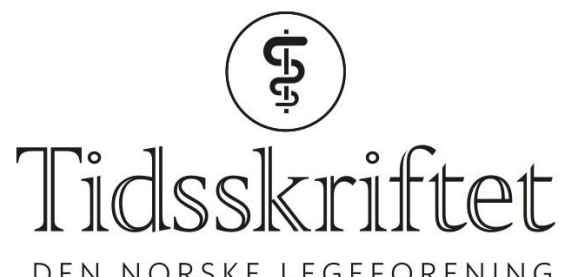

DEN NORSKE LEGEFORENING

\title{
N.G. Juel svarer
}

KOMMENTAR

NIELS GUNNAR JUEL

E-post: n_gj@hotmail.com

Niels Gunnar Juel er overlege ved Avdeling for fysikalsk medisin og rehabilitering, Oslo universitetssykehus, Ullevål.

Ingen oppgitte interessekonflikter.

Siste systematiske oversikt fra Cochrane vedrørende Frozen shoulder konkluderer med at $\emptyset v e l s e r$ supplert med manuell behandling er mindre effektivt enn en steroidinjeksjon på kort sikt (6-8 uker) og at det er usikker dokumentasjon på lang sikt. Frozen shoulder har et godartet forløp og smertebehandling i den smertefulle fasen er det viktigste for pasientene. Trengs smertebehandling er injeksjon best dokumentert (1).

Noen få pasienter kan ha nytte av muskulær behandling og kanskje veiledning fra fysioterapeut når skulderen er mindre smertefull. Dette gjelder få personer og det vil være mot kampanjen «Gjør kloke valg» å sende alle pasienter med frozen shoulder til oppfølging av fysioterapeut.

$\emptyset$ velsesbehandling og veiledet trening er en godt dokumentert behandling ved subakromiale smerter. Enkle øvelser som de anbefalte er lette å instruere, lette å gjennomføre og lite smerteprovoserende. De aktiverer skulderbladets muskler og rotator mansjetten som anbefales i alle programmer. Øvelsene egner seg godt i

primærhelsetjenesten. Når det gjelder mer avansert øvelsesbehandling er det som tidligere replisert, ingen konsensus om hvilket øvelsesutvalg som gir best effekt for pasienten (2). Dersom det er behov for videre oppfølging hos fysioterapeut regner vi med at terapeuten vurderer behovet for mer utfordrende øvelser sammen med pasienten i lys av andre faktorer av betydning for pasientens prognose.

\section{LITTERATUR:}

1. Page MJ, Green S, Kramer S et al. Manual therapy and exercise for adhesive capsulitis (frozen shoulder). Cochrane Database Syst Rev 2014; 8: CDo11275. [PubMed]

2. Shire AR, Stæhr TAB, Overby JB et al. Specific or general exercise strategy for subacromial impingement syndrome-does it matter? A systematic literature review and meta analysis. BMC Musculoskelet Disord 2017; 18: 158. [PubMed][CrossRef] 